\title{
Når roboter styrer sykehus
}

\author{
Lokalsykehusstrider er ofte steile - det kjempes om eksistens og faglig ære. På Sørlandet har en privat \\ investor gitt en kirurgirobot som gave til sykehuset, med krav om hvor den skal plasseres og brukes. \\ Det er etisk problematisk at sykehus tar imot gaver som styrer funksjonsfordelingen og prioriteringene.
}

Bjørn M. Hofmann

b.m.hofmann@medisin.uio.no

Det har i mange år vært strid mellom sykehusene i Arendal og Kristiansand. Tidlig i 2012 hadde ledelsen ved Sørlandet sykehus bestemt at behandling av prostatakreft og nyrekreft skulle skje ved sykehuset i Kristiansand. Ansatte ved sykehuset og beboere i Arendal har følt seg utsatt for en systematisk nedbygging etter at flere behandlingsformer er lagt til Kristiansand, og vedtaket ble av mange oppfattet som «spikeren i kista» for sykehuset i Arendal (1).

Investoren Ole G. Ottersland fra Arendal «kastet seg inn i kampen for å få omgjort vedtaket» og tilbød seg å donere en kirurgirobot (da Vinci-robot) til en verdi av 25 millioner kroner til Sørlandet sykehus. Forutsetningen var at roboten skulle plasseres i Arendal (2) og følgelig at behandlingen av prostatakreft og nyrekreft skulle foregå her. Politikerne i Arendal engasjerte seg sterkt - det «er utenkelig å si nei til en slik gave på 25 millioner kroner», ble det sagt (1).

Ledelsen ved Sørlandet sykehus prøvde å stå ved sitt vedtak om at behandling av prostatakreft og nyrekreft skulle legges til Kristiansand, men på en slik måte at gaven kunne tas imot. Dette reagerte Ottersland kraftig på (3), og han truet med å trekke gaven tilbake (4). I begynnelsen av juni 2012 ble man enige om en avtale der roboten skulle plasseres i Arendal (5).

Som med mange sykehusgaver, følger det med en rekke drifts- og vedlikeholdskostnader. Her har Ottersland tilbudt seg å dekke en fire års serviceperiode. Sykehuset hadde forstått det slik at gaven dekket servicekostnadene i fem år, noe som vil medføre ekstrakostnader for sykehuset (i 2017) (6), men også dette er man nå blitt enig om. Gaven ankom Arendal i begynnelsen av desember 2012 og skal tas i bruk tidlig i 2013 (6-7).

Med denne gaven styrer en ekstern privat aktør funksjonsfordelingen og den interne aktiviteten ved et stort norsk sykehus. Dette reiser flere interessante spørsmål. Det første er hvordan helsevesenet skal forholde seg til gaver.

\section{Gaver med bindinger}

Gaver styrker gjensidighet og sosiale bånd (8). Selv når gaver bygger på altruisme, er det naivt å tro at det finnes «rene gaver» som er helt uten bindinger (9). Det finnes ingen gratis lunsj, som det gjerne sies. Gaver fyller en rekke funksjoner - de kan signalisere nærhet, gjensidighet og takknemlighet, men også takknemlighetsgjeld, skam og skyld. Gaver kan brukes til å differensiere og til å dreie oppmerksomhet og prioritering.

En gave har alltid et motiv, og motivet er ikke alltid bare nestekjærlighet. Gaver kan gis til helsevesenet for å fremme arbeidet

\section{«Bindingen ved gaver er sjelden så tydelig som i robotsaken på Sørlandet»}

med en pasientgruppe, for å markedsføre personer, organisasjoner eller firmaer og for å sikre drift ved spesifikke sykehus, slik som ved Sørlandet sykehus. Ofte er det en kombinasjon av flere motiver.

Helsepersonells forhold til gaver er regulert i egen forskrift (10), og flere helseforetak har egne retningslinjer for helseforetakenes forhold til gaver, stiftelser og legater (11). Her er gave definert på følgende måte: «Med gave forstås enhver vederlagsfri overføring av en formuesverdi eller formuesposisjon, f.eks. fast eiendom, løsøre, verdipapirer, penger, gjenstander eller liknende, uavhengig om overføringen er øremerket til et eller flere bestemte formål eller ikke. Overføring på grunnlag av testamente (arv) likestilles med gave, likeså overføring av formuesverdier til underpris» (11).

Definisjonen strider altså mot standard gaveteori når den forutsetter at gaver er vederlagsfrie, det vil si at de gis uten gjengjeldelse, motytelse eller godtgjøring. Er kirurgiroboten på Sørlandet en gave?

\section{Uten vederlag?}

På Sørlandet forlangte giveren noe tilbake: plassering i Arendal. Dersom man anerkjenner dette som en reell motytelse, er roboten ingen gave og faller utenfor det sykehuset kan motta. Det vil kanskje være mer naturlig å kalle det for en betinget gave. Problemstillingen er ikke ny: Da Ronald McDonald Barnefond ville gi penger (16 millioner kroner) til et sykehotell ved Rikshospitalet, forlangte man at sykehotellet skulle hete «Ronald McDonald-huset» (12). Det avslo Rikshospitalet.

Retningslinjene tar tydelig høyde for at gaver kan brukes for å påvirke strategier og funksjonsfordelinger og at de kan få følger for budsjetter og prioriteringer. Likevel er de innholds- og retningsløse: «Det forutsettes at gaver av uvanlig art eller størrelser, eller gaver som kan ha innvirkning på foretakets vedtatte strategier eller prioriteringer, forelegges styret før gaven aksepteres.

Likeså forutsettes at gaver som kan påvirke funksjonsfordelingen mellom helseforetak, eller som har konsekvens for investeringsplan skal behandles av styret i RHF før det aksepteres». Så lenge saken blir behandlet i styret, er det ok.

\section{Rettferdige gaver?}

En av følgene av gavenes bindinger er altså at de kan dreie helsevesenets oppmerksomhet, for eksempel mot visse sykdommer, pasientgrupper og teknologier eller påvirke sykehusorganiseringen. Når gaver fører til at man retter oppmerksomheten mot sykdommer som ellers får lite oppmerksomhet eller har lav prestisje, kan dette være positivt. Dersom gavenes bindinger fører til markedsføring av eksterne aktører eller til skjulte prioriteringer, er det mer problematisk.

Gaver oppstår og forekommer i omgivelser med overskudd - hvor man er mest kjent med og opptatt av sykdommer med høy status og prestisje. Gavenes effekt på rettferdig fordeling er derfor ofte begrenset. 


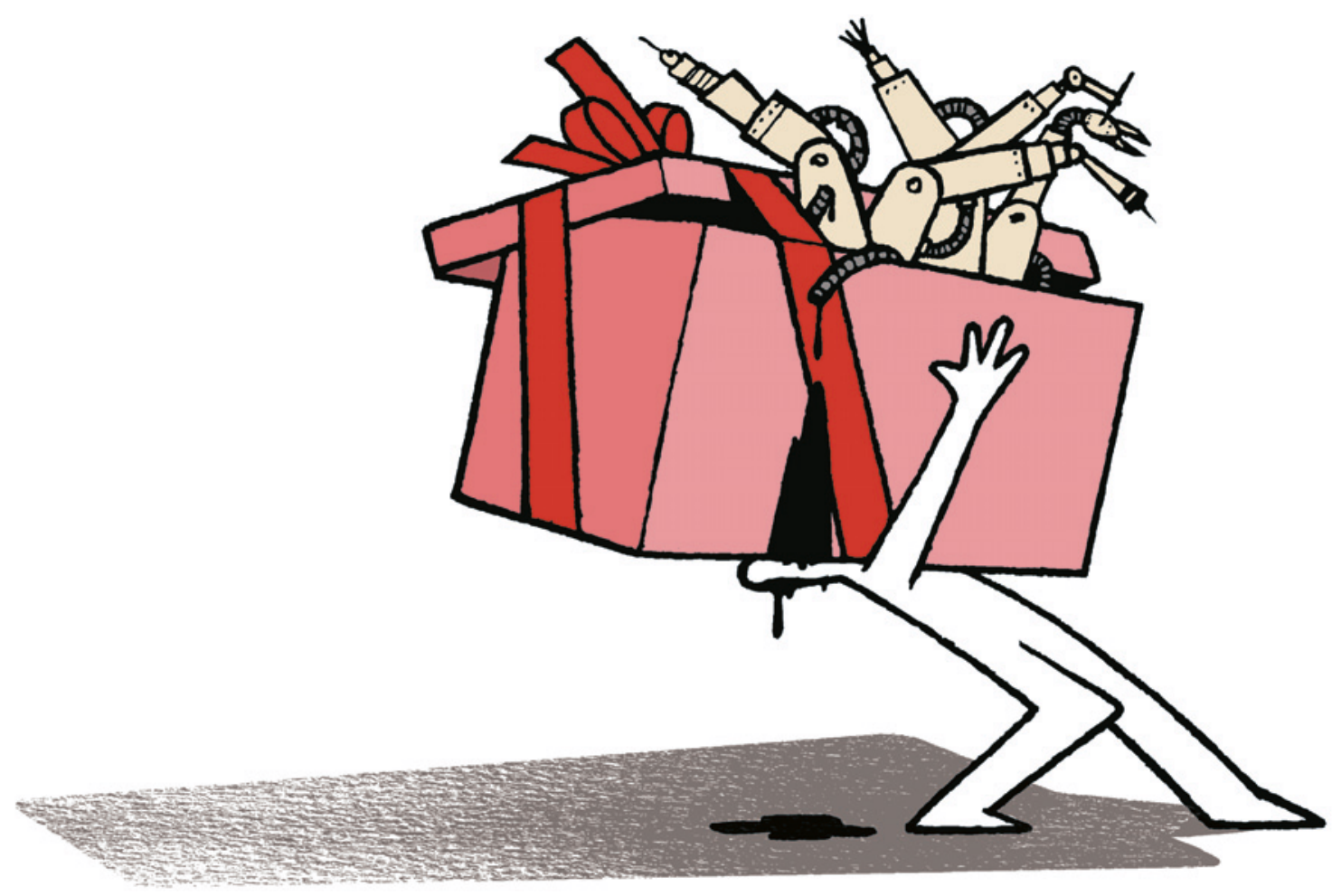

Illustrasjon Supernøtt popsløyd

\section{Gave til ingen nytte?}

Som privatpersoner er vi ukomfortable dersom vi mottar en gave som vi ikke har bruk for eller glede av. Selv om vi kan sette gaven på loftet, kaste den eller gi den til trengende, så hefter gjensidighetens ubehag ved den. Vi blir fanget av en form for gjeld uten noen gevinst.

Hvordan er det så med gaver som gis til helsevesenet? Der forutsetter vi at gavene er nyttige, fordi helsevesenet jo er til beste for folks helse. Men er robotkirurgi til nytte? I to relativt ferske kunnskapsoppsummeringer konkluderes det med at dokumentasjonen for robotassistert kirurgi er av forholdsvis lav kvalitet, men at det er liten forskjell mellom robotassistert kirurgi, åpen kirurgi og laparoskopisk kirurgi ved prostatektomi (13-14). De er ingen vesentlig forskjell i dødelighet, sykelighet, livskvalitet og tilbakefall. Robotassistert kirurgi resulterer i litt kortere liggetid, litt mindre blodtap og noe bedre seksuell funksjon, men tar lengre tid og gir økte kostnader.

Mye kan derfor tyde på at pasientene får liten nytte av den rause gaven på Sørlandet. Fagmiljøene, helsepolitikerne og inves- toren, derimot, får full uttelling. Helseforetaket vinner i praksis svært lite - det får ekstrakostnader til drift og vedlikehold, mister styrekraft og må om 5-10 år erstatte utstyr som ikke har kommet inn gjennom vanlige anskaffelsesprosesser.

\section{Lar sykehus seg kjøpe?}

Lar sykehus seg styre gjennom gaver? Eksemplet fra Sørlandet viser klart at så er tilfellet. Er det riktig at sykehusene lar seg styre på denne måten?

Dersom helsegevinsten ved robotkirurgi var stor og helseforetaket ikke kunne oppnådd denne gevinsten uten å motta gaven, er det ikke vanskelig å se at styret ville hatt et vanskelig valg. Men i dette tilfellet er helsegevinsten $\mathrm{i}$ beste fall mager - og styringstapet stort.

Retningslinjene for gaver er tydelige. Gaven burde ha vært avvist. Det burde ha holdt å vise til at giver stiller betingelser, at nytten av robotkirurgi er begrenset og at dokumentasjonen for nytte er av dårlig kvalitet. En viktig grunn til at dette tydeligvis ikke var nok i praksis, er sannsynligvis teknologiens magiske kraft i helsevesenet.

\section{Teknologiens magi}

Teknologien har funksjoner langt utover sitt tekniske formål - den er knyttet til håp, fremskritt og prestisje $(15,16)$. Helsepersonell kan føle at de er styrt av teknologien, men også at de bruker teknologien strategisk. På Sørlandet har man klart uttrykt at teknologien brukes til å gjøre arbeidsplassene interessante og holde på fagfolkene (7).

En rapport fra Nederland viser hvilke mekanismer som gjør seg gjeldende ved anskaffelse av kirurgiroboter (17). Behovet for en robot oppstår fordi produsenter, leverandører, helsepersonell, mottakere (pasienter) og betalere påvirker hverandre til å tro at dette representerer fremskritt, prestisje og at man beveger seg over til nye og mer fruktbare faglige plattformer, preget av teknisk presisjon og ergonomiske fordeler. Godt hjulpet av mediene, som fremstiller robotkirurgien som «fremskrittet vi ikke kan stoppe» og som det vil være selvdestruktivt ikke å anskaffe, resulterer den gjensidige forsterkningen av disse behovene $i$ en etterspørsel etter robotkirurgi.

Deretter oppstår et press til å bruke roboten til stadig nye operasjoner når den er anskaf- 
fet (17). Dette viser at det ligger sosiale og (helse- og fag)politiske interesser og mekanismer bak teknologiens tilsynelatende magiske effekt i helsevesenet (18). Derfor er også teknologigaver så virksomme.

\section{Avslutning}

Sørlandet sykehus burde ikke ha takket ja til en gave som gis med klare intensjoner om å påvirke sykehusets strategi, funksjonsfordeling og prioriteringer. Utbyttet for pasientene er usikkert og magert. Dersom man legger mer vekt på nærhet enn på nytte, vil gaven kunne være til berikelse for fagmiljøet i Arendal og for giveren, og sannsynligvis også befolkningen i Arendal og omegn. På den annen side binder gaven ledelsen i helseforetaket og reduserer deres styringskraft.

Bindingen ved gaver er sjelden så tydelig som i robotsaken på Sørlandet. Samtidig viser den hvor magisk teknologien er. En gave på 25 millioner kroner til en samtalebasert terapi med godt dokumentert effekt hadde neppe styrket eller reddet sykehuset i Arendal.

Det er etisk problematisk at sykehus tar imot gaver som styrer funksjonsfordeling og prioriteringer ved sykehuset. Saken viser at helseforetakenes retningslinjer for gaver ikke gir noen begrensninger - ut over at slike saker skal styrebehandles. Sykehusene er til salgs - ikke for knapper og glansbilder - men for teknologi, eller mer spesifikt: kirurgisk teknologi, både for hjerte, hjerne og organer under beltestedet.
Kronikken er basert på et foredrag på et seminar arrangert av Nasjonalt råd for kvalitet og prioritering i helsetjenesten 30.11. 2012.

\section{Bjørn M. Hofmann (f. 1964)}

er professor i medisinsk etikk ved Høgskolen i Gjøvik og ved Universitetet i Oslo og forsker ved Nasjonalt kunnskapssenter for helsetjenesten. Han forsker og underviser i medisinsk filosofi, vitenskapsteori og etikk. Forfatter har fylt ut ICMJE-skjemaet og oppgir ingen interessekonflikter.

\section{Litteratur}

1. Refseth A, Raustøl H, Sundsdal S. Robotgave kan bedre samarbeidet. NRK Sørlandet 21.5.2012. www.nrk.no/nyheter/distrikt/sorlandet/1.8146210 (21.12.2012).

2. Sellevold T. Vil gi kreftmaskin til Arendal. NRK Sørlandet 27.3.2012. www.nrk.no/nyheter/distrikt/ sorlandet/1.8052921 (21.12.2012).

3. Eskedal $\emptyset$. Sundsdal S, Nilsen AT. Ottersland - Stoler ikke på dere. NRK Sørlandet 23.5.2012. www.nrk.no/nyheter/distrikt/sorlandet/1.8151405 (21.12.2012).

4. E-post fra Peder Olsen til Ottersland. Udatert. http://sorlandet-sykehus.no/SiteCollection Documents/Epost\%20fra\%20Peder\%20 Olsen\%20til\%200ttersland.pdf (21.12.2012).

5. Larsen LE, Andersen EW Sundsdal $S$ et al. Løsning $\mathrm{i}$ «robotstrid». NRK Sørlandet 4.6.2012. www.nrk.no/nyheter/distrikt/sorlandet/1.8176871 (30.12.2012).

6. Sellevold T. Sykehusgave ble ikke helt gratis. NRK Sørlandet 27.11.2012. www.nrk.no/nyheter/ distrikt/sorlandet/1.8834635 (21.12.2012)

7. Dagsvik S. Dette er helt klart verdt pengene. Sørlandet sykehus 11.12.2012. http://sorlandetsykehus.no/aktuelt/nyheter/Sider/-dette-er-heltklart-verdt-pengene.aspx (30.12.2012).

8. Mauss M. The gift : The form and reason for exchange in archaic societies. London: W.W. Norton, 1990
9. Douglas M. Risk and blame: essays in cultural theory. London: Routledge, 1992

10. Forskrift om begrensninger i helsepersonells adgang til å motta gave, provisjon, tjeneste eller annen ytelse. Forskrift 29. august $2005 \mathrm{nr}$. Rundskriv I-13/2005. www.regjeringen.no/upload/ kilde/hod/rus/2005/0014/ddd/pdfv/260977rundskriv_1-13_2005_korrigert_101005_5.pdf (29.1.2013).

11. Helse Sør-Øst. Retningslinjer for helseforetakenes forhold til gaver, stiftelser og legater. sorlandetsykehus.no/SiteCollectionDocuments/ retningslinjer\%20for\%20gaver.pdf (29.1.2013).

12. Aasdalen D, Granbo K. McDonalds krever navneære for sykehotell. NRK Østlandssendingen 1.7.2008. www.nrk.no/nyheter/distrikt/ ostlandssendingen/1.6121624 (29.1.2013)

13. Ho C, Tsakonas E, Tran K et al. Robot-assisted surgery compared with open surgery and laparoscopic surgery: Clinical effectiveness and economic analyses. Ottawa: Canadian Agency for Drugs and Technologies in Health, 2011. Technology report nr. 137. www.cadth.ca/en/products/ health-technology-assessment/publication/2682 (29.1.2013)

14. Health technology assessment of robot-assisted surgery in selected surgical procedures. Cork: Health Information and Quality Authority, 2011. www.hiqa.ie/publications/health-technologyassessment-robot-assisted-surgery-selectedsurgical-procedures (29.1.2013).

15. Hofmann B. The technological invention of disease - on disease, technology and values. Doktoravhandling. Oslo: Universitetet i Oslo, 2002.

16. Lin R, Amney K, Bekley GA. Robotic ethics: The ethical and social implications of robotics. Boston, MA: MIT Press, 2012

17. Abrishami A. Da Vinci surgery: Is it a no-brainer? Robot-assisted prostate surgery in the mirror of social health insurance. Diemen: Dutch Health Care Insurance Board, 2011

18. Hofmann B. Is there a technological imperative in health care? Int J Technol Assess Health Care 2002; 18: 675-89.

Mottatt 4.1. 2013, første revisjon innsendt 28.1. 2013, godkjent 29.1. 2013. Medisinsk redaktør Petter Gjersvik. 